\title{
FAIR TRADE AS A TOOL OF CORPORATE SOCIAL RESPONSIBILITY
}

\author{
Katarína Moravčíková ${ }^{1}$, Elena Gregová ${ }^{2}$
}

\begin{abstract}
Fair Trade connects developed countries, where greater sustainability and justice is being sought, with the needs of developing countries where economic and social changes are needed most. It enables citizens who are consumers to favor the producers of poorer countries. This is a manifestation of humanity that helps producers to escape acute poverty and lead dignified lives. Fair trade is becoming a very "hot" topic, not only for businesses but also for consumers, who are trending towards buying Fair Trade products. By buying such products, customers express solidarity with the producers of Fair Trade products. This article aims to identify the importance of Fair Trade. Methods of analysis, synthesis, deduction, and comparison are used to establish the current situation of Fair Trade in Slovakia and the Czech Republic, as well as the perception of Fair Trade held by Czech and Slovak customers.
\end{abstract}

JEL Classification Numbers: M14, M31, M39, DOI: http://dx.doi.org/10.12955/cbup.v4.778

Keywords: fair trade, corporate social responsibility, customer, product.

\section{Introduction}

Among the major challenges that face developing countries are the continuing small number of jobs, lack of healthcare and social security, low wages, weak labor laws, and lack of environmental protection. Producers from developing countries around the world sell their products for very low to "unfair" prices, while the ideal consumer buys these products at prices that are usually much higher in comparison, due to the large number of commercial intermediaries (Hraskova \& Bartosova, 2014). Hence, the initiative of Fair Trade was created and seeks a fair distribution of income from trade between developing and developed countries. The Fair Trade movement was created after World War II. The first non-profit organization in the world was an American nongovernmental organization, which started trading with poorer countries at the end of the 1940s (Kuldova, 2012).

\section{Corporate Social Responsibility}

The modern history of Corporate Social Responsibility (CSR) began to develop in the 1950s, when the concept of CSR fully penetrated the literature of managers. Howard Rothmann Bowen, who wrote "Social Responsibilities of the Businessman" in 1953, is considered the first theorist of the CSR concept (Tokarcikova, Bartosova, Kucharcikova, \& Durisova, 2014). Rapid development and a considerable breath of scope in this concept have resulted in large inconsistencies regarding its terminology. Bowen (2013) defines CSR as "the commitment of entrepreneurs to seek such policies, make such decisions or carry out such activities that are needed to the objectives and values of our society". According to the European Commission (2001), CSR is "voluntary integration of social and ecological interests to daily company activities and interactions with company stakeholders".

Kotler and Lee (2005) reported six instruments of CSR activities, through which an enterprise can promote the health of society, security, education, and employment, and improve the environment, social, and economic development, and other basic human needs and desires. A company can carry these out supported by a number of tools, such as:

1. Campaigns expanding awareness of the social problem, where the company takes the initiative to increase awareness through campaigns and particularly, public interest in the social problem or issue and persuades them to support the campaign by donating time, volunteering, or giving financial or non-financial gifts;

2. Cause-related marketing, which involves marketing activities associated with community projects. A company pays a certain amount of revenue from a particular product for social

\footnotetext{
${ }^{1}$ Katarína Moravčíková, Faculty of Operation and Economics of Transport and Communications,University of Žilina, Slovakia, katarina.moravcikova@fpedas.uniza.sk

${ }^{2}$ Elena Gregová, Faculty of Operation and Economy of Transport and Communication, University of Žilina, Slovakia, elena.gregova@fpedas.uniza.sk
} 
activities or non-profit organization. It also tries to attract customers into buying, which increases company revenues and profit organization;

3. Social marketing, which is the development and implementation of campaigns to change behavior directed towards improving public health, safety, the environment, or the well-being of society;

4. Corporate philanthropy, which is the direct contribution from enterprises to charity or a social problem, most commonly in the form of cash grants, subsidies, or contributions;

5. Corporate volunteering, an initiative in which the company encourages employees, business partners, and members of the franchise to voluntarily donate their time to support local organizations and social problems; and

6. Socially responsible business practices, where the company voluntarily implements business activities and investments, through which the conditions in the local community, whether social or environmental, are improved.

Kuldová (2012) assigned two others to these instruments, namely:

1. Outplacement, which provides support and assistance in placing redundant workers in the labor market, to counteract the negative effects of redundancies; and

2. Fair Trade, where the aim of this partnership between the manufacturer and the buyer is to support disadvantaged producers in developing countries by controlling fair trading, labor rights, non-use of child labor in the production, and environmental protection, as well as disseminating awareness in developed countries about the situation of these producers.

\section{Fair Trade as a tool of Corporate Social Responsibility}

Fair Trade is an international term used for ethical trading involving small farmers in developing countries and to promote sustainability (Masarova, Stefanikova, \& Rypakova, 2014). Fair Trade aims to help people in third world areas to make a living through their own work and thus free them from the poverty carousel. Fair Trade is not just one organization. It is a movement that brings together diverse groups of people (Kuldova, 2012).

There are several definitions of Fair Trade, but the most common is that of the International Association, FINE. According to FINE, Fair Trade is:

business partnership, which aims to improve the living conditions of the excluded and disadvantaged producers in developing countries within the concept of sustainable development. It seeks to achieve by providing better trading conditions for producers and increase consumer awareness of the situation in the poor developing countries. (Spolecnost pro Fair Trade, n.d.)

According to the World Trade Organization (WTO), Fair Trade is:

a trading partnership based on dialogue, transparency and respect, which aims to

achieve greater equity in international trade. It contributes to sustainable development by providing better trading conditions and protects the rights of marginalized producers and workers especially in countries of the Global South. (Drienikova, Gavalova, \& Obadi, 2010, p. 34)

The basic objective of Fair Trade is to assist residents in developing countries to live in dignity. The many goals closely related with this objective, according to Hejkrlik (2004), and these include:

- Improve living conditions for producers in developing countries by improving their access to markets, strengthening the organizations of primary producers, and purchasing for better prices;

- Promote the development of disadvantaged producers, especially women and traditional peoples, and to protect children from labor exploitation;

- Raise awareness among consumers about the negative impacts of international trade on producers, to take advantage of their purchasing power positively (Nadanyiova \& Kramarova, 2013);

- Lead campaigns for changes in the rules and practice of conventional international trade;

- Provide quality products at a reasonable price with a guarantee of origin; and 
- Enable consumers to contribute to the reduction of poverty by buying Fair Trade products.

The basic range of Fair Trade consists of food commodities, such as coffee, tea, spices, rice, fruit, and sugar. The Fair Trade label can also be used for hand-made products. Under the conditions of Fair Trade, musical instruments, jewelry, clothing and toys can be bought as well (Spolecnost pro Fair Trade, n.d.).

The majority of consumers around the world buy products from developing countries every day. The path of these products to the customer is very demanding (Lehutova, Krizanova, \& Kliestik, 2013). In the case of Fair Trade this process is more difficult. Fair Trade growers use no chemicals or chemical agents; and growing Fair Trade products takes considerable time, and is respectful of nature and human health (Bachanova, Corejova, \& Rostasova, 2009). Fair Trade growers cooperate in teams responsible to them. The grower's main task is to complete the contract with customers for at least one year. This contract guarantees for the grower and their team that their products will be sold. Then the importer, who is a company certified as Fair Trade, becomes involved. This company buys the products from the team and distributes them to the countries concerned. Products must be marked by a registration mark showing Fair Trade before being on sold to shops (Drienikova et al., 2010).

There are some differences between Fair Trade and traditional trade. Fair Trade exchange differs from traditional trade notably by its basic objectives, i.e. Fair Trade seeks the long-term sustainable development of manufacturers and their products, and offers the opportunity for consumers to purchase quality products at fair prices. Its main objective is not profit maximization, unlike traditional trade, but rather maximizing the satisfaction of small producers as well as consumers (Majerova \& Krizanova, 2014). A trademark is a guarantee of product quality for the consumer, and includes the assurance that the product derives from a Third World country, and is made in accordance with environmental protection and without forced or child labor (Spolecnost pro Fair Trade, n.d.).

\section{The current situation of Fair Trade in Slovakia and Czech Republic}

In recent years, the interest of Czech and Slovak populations for products bearing the Fair Trade label has greatly increased. This positive trend can be attributed to increased awareness, and also increased public education, regarding several Fair Trade organizations devoted to trade in Slovakia and the Czech Republic. Data show an ever increasing turnover in the Czech Republic with increased demand for Fair Trade products. Fairtrade Czech Republic and Slovakia publishes an annual report, which provides information on the sale of Fair Trade products. The 2014 report showed Czech consumers spent a total of $€ 7.5$ million in 2014 (Figure 1) for products with the Fair Trade mark. This was a 17\% increase in retail trade turnover from the previous 2013 year. People increasingly support small-scale farmers of the Global South by increasing their consumption of the farmer's goods (Fairtrade Czech Republic and Slovakia, 2014).

Fairtrade Czech Republic and Slovakia provided the results of the retail trade turnover in Slovakia for the first time in 2014, showing total sales of products with the Fair Trade mark in Slovakia of 1.1 million euros.

The best-selling Fair Trade product was coffee for several years in the Czech Republic. In 2014, 190 tons of this commodity, valued at 5.1 million euros, was sold. It constituted $68 \%$ of the total retail turnover of Fair Trade products (Figure 2). Products from Fair Trade cotton, which constitute 16\%, and tea, for which consumers spent 0.5 million euros, complete the trinity of best products (Figure 2) (Fairtrade Czech Republic and Slovakia, 2014).

In Slovakia, coffee had the most important position. Revenues from coffee represent $73 \%$ of total turnover (Figure 3). In second place are cosmetic products with $8 \%$, which differs significantly to the Czech market. Following this is tea with $7 \%$, processed foods such as ice cream, cookies, and jams with 6\%, and cocoa and chocolate with 5\% (Figure 3) (Fairtrade Czech Republic and Slovakia, 2014).

The company, Ipsos, conducted the research project "Perceptions of Corporate Social Responsibility and the impact on the reputation of the company" in 2013 in the Czech Republic, on a population sample size of 1,019. According to the research, most respondents bought socially responsible products, primarily energy-efficient equipment, such as light bulbs and various types of appliances (Figure 4). In 2013, more than half the households bought products made from recycled materials and 
a third bought organic products, while $29 \%$ of the Czech respondents focused on Fair Trade products (Figure 4) (Ipsos, 2013).

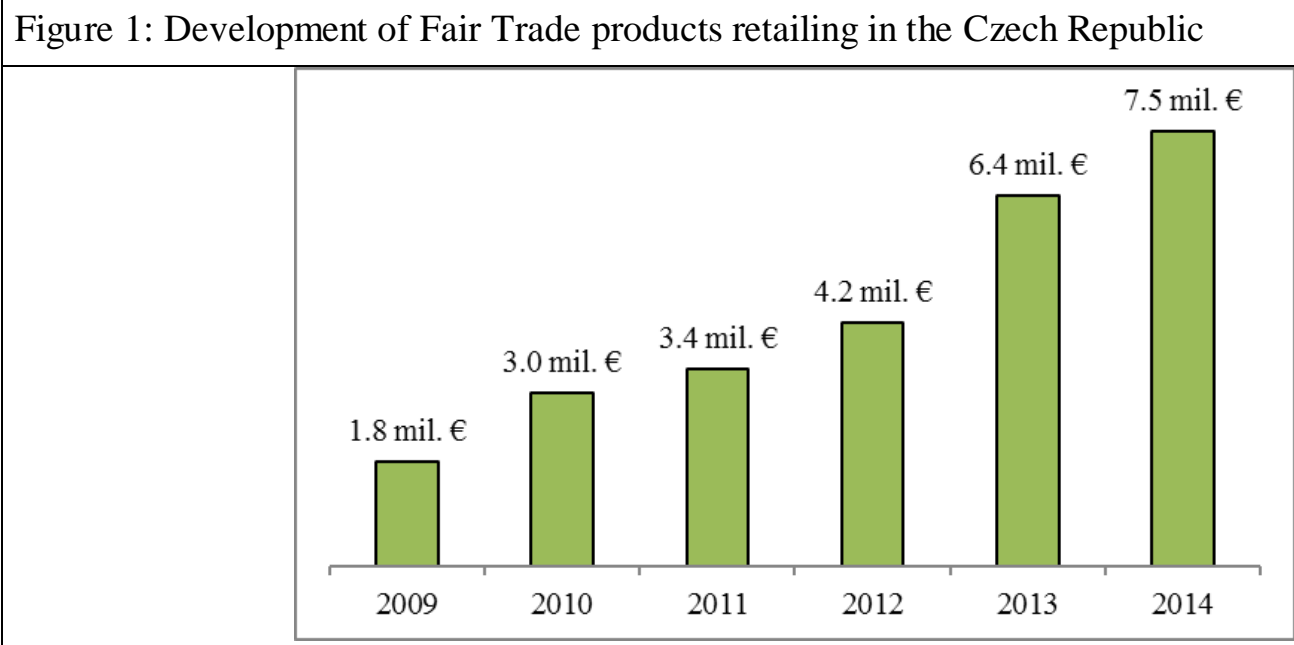

Source: Fairtrade Czech Republic and Slovakia (2014)

Figure 2: Sale of Fair Trade products in the Czech Republic in 2014

口coffee
$\square$ cotton
$\square$ tea
口processed food
$\square$ cocoa, chocolate
$\square$ cosmetics
$\square$ beverages
$\square$ other

Source: Fairtrade Czech Republic and Slovakia (2014)

Figure 3: Sale of Fair Trade products in Slovakia in 2014

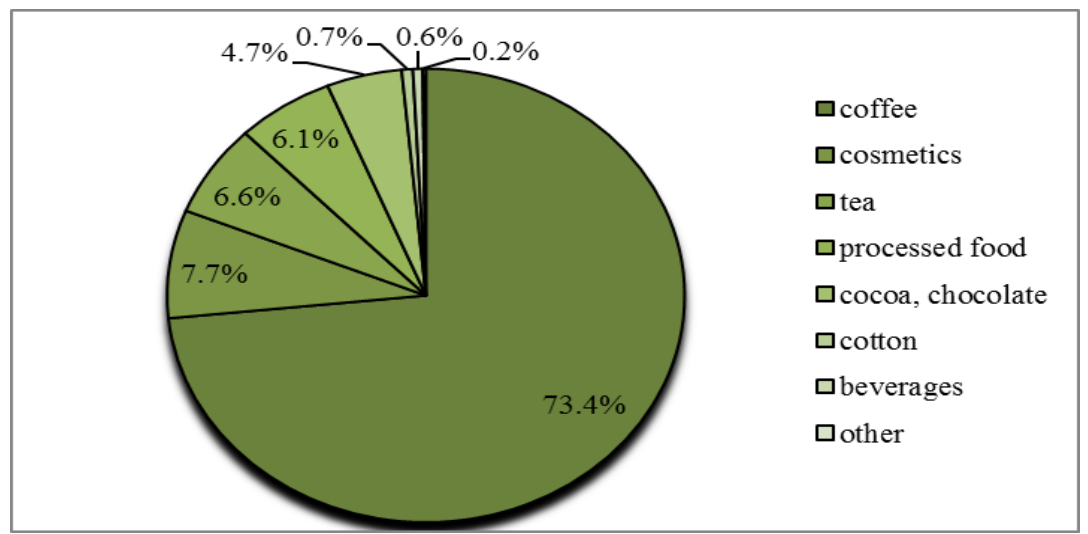

Source: Fairtrade Czech Republic and Slovakia (2014) 
Figure 4: Purchase of socially responsible products by customers in the Czech Republic in 2013

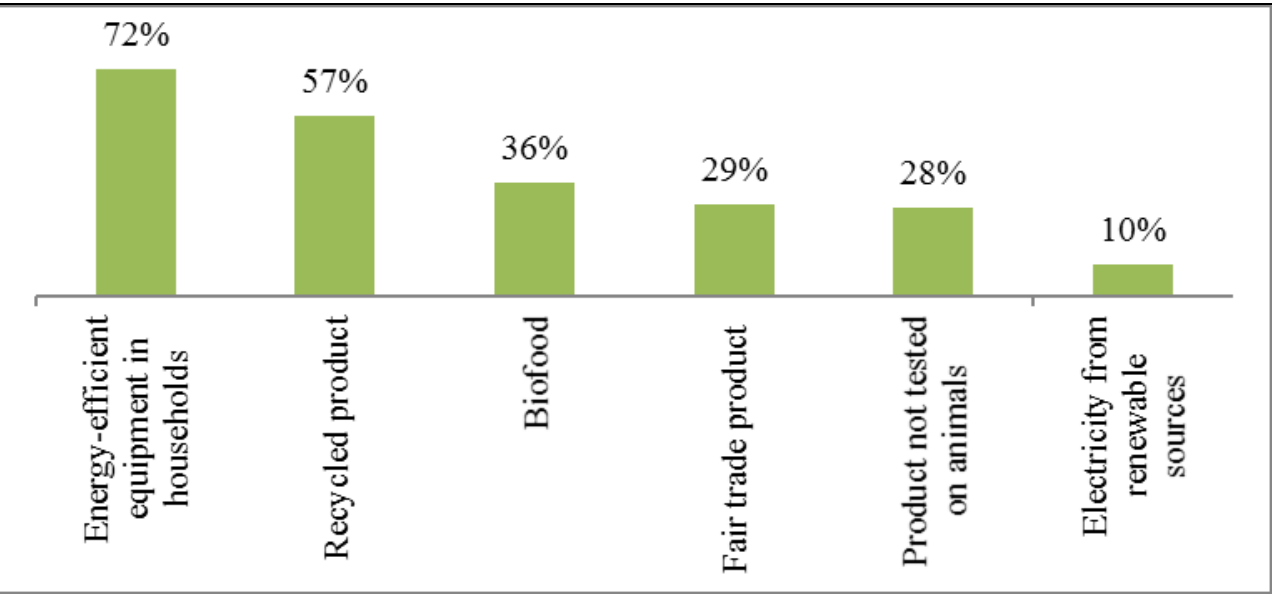

Source: Ipsos (2013)

In 2015, the Department of Economics, University of Žilina, conducted a survey called "The perception of corporate social responsibility on the part of customers", which involved 394 Slovak respondents. This survey showed that the most social responsibly products purchased in Slovakia (80\% of respondents) were energy-efficient equipment (Figure 5). The second most frequently purchased products were recycled and organic food products (55\% of respondents each) followed by Fair Trade products that were purchased by $30 \%$ of Slovak respondents (Figure 5).

Figure 5: Purchase of socially responsible products by customers in Slovakia in 2015

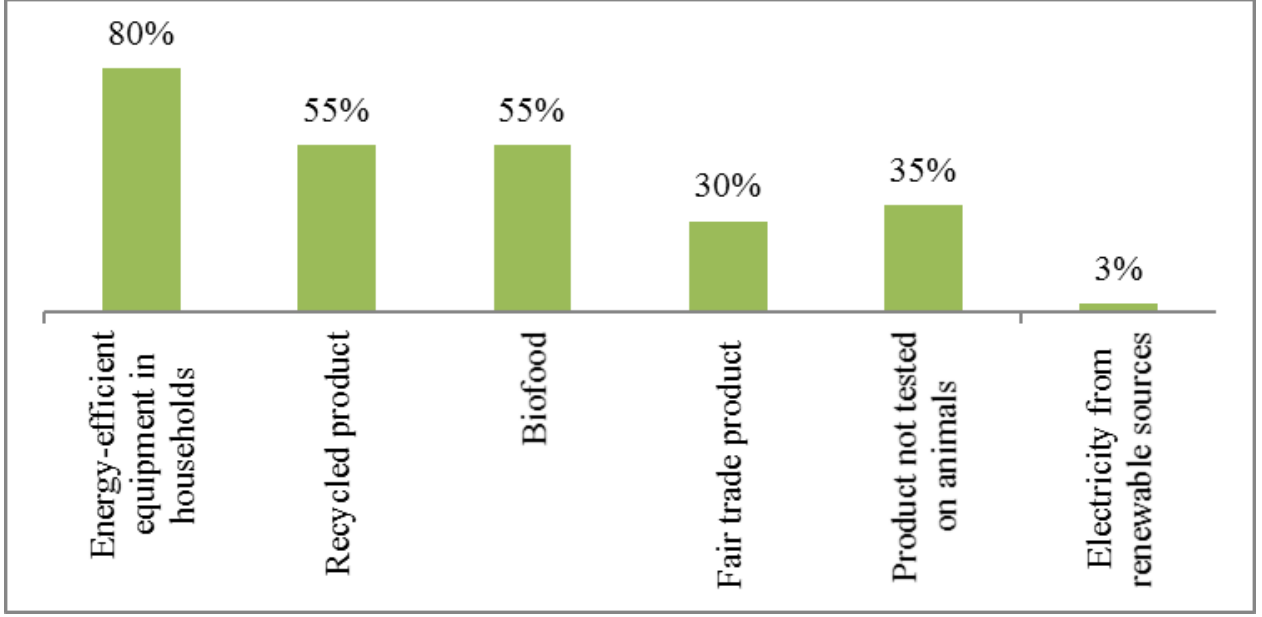

Source: Authors

Popularity and interest in Fair Trade products in Slovakia and the Czech Republic is growing, as evidenced by the retail trade turnover, which increased from year to year. Fair Trade products were bought by about a third of the Czech and Slovak respondents (Figures $4 \& 5$ ) with coffee the most purchased Fair Trade product (Figures $2 \& 3$ ).

\section{Conclusion}

The Fair Trade concept aims to enable people in developing countries to gain a "decent" life. It attempts to ensure that farmers in developing countries are paid the largest percentage from sale of their products. Awareness of Slovak and Czech Republic customers on the subject continues to grow, as evidenced by the information on the quantity of Fair Trade products purchased by respondents. 
Czech Republic and Slovak consumers have similar interest in Fair Trade products. In both countries, coffee is the most popular Fair Trade product.

\section{Acknowledgement}

This contribution is a partial output of scientific grant VEGA n. 1/0024/15: The fundamental research perception of corporate social responsibility as a value for customer.

\section{References}

Bachanova, P., Corejova, T., \& Rostasova, M. (2009). The green issues of postal industry in Europe. 3rd Central European Conference in Regional Science, 901-905.

Bowen, H. R. (2013). Social Responsibilities of the businessman. pp. 248.

Drienikova, K., Gavalova, V., \& Obadi, S. M. (2010). Economy and trade policy developing countries. Bratislava EKONOM, 2010, 34-35.

European Commission (2001). Green Paper - Promotion a European framework for corporate social responsibility, $2001,74$.

Fairtrade Czech Republic and Slovakia (2014). Annual report 2014-2015, retrieved from http://www.fairtrade-cesko.cz/\#!premedia/vyrocne-spravy

Hejkrlik, J. (2004). Fair Trade: Fair Trade in the Czech Republic. Association for Fair Trade, 2004, 20.

Hraskova, D., \& Bartosova, V. (2014). Process based Management in a Profile and Objectives of the Transport Company. 2nd International Conference on Economics and Social Science (ICESS), Advances in Education Research, 2014, 109-115.

IPSOS, s.r.o (2013). The perception of corporate social responsibility and the impact on the reputation of companies, 2013 , from http://www.cma.cz/wp-content/uploads/2014/02/Studie-Ipsos-CSR-RESEARCH-2013_ve\%C5\%99ejn\%C3\% A1$\% \mathrm{C} 4 \% 8 \mathrm{D} \% \mathrm{C} 3 \% \mathrm{~A} 1 \mathrm{st} . \mathrm{pdf}$

Kotler, P., \& Lee, N. (2005). Corporate Social Responsibility, USA: John Wiley \& Sons, pp. 307.

Kuldova, L. (2012). Corporate social responsibility: business ethics and social responsibility in practice. Kanina OPS, 2012 , 189.

Lehutova, K., Krizanova, A., \& Kliestik, T. (2013). Quantification of Equity and Debt Capital Costs in the Specific Conditions of Transport Enterprises. 17th International Conference on Transport Means, Transport Means., Kaunas Univ Technol, Kaunas, Lithuania, 2013, 258-261.

Majerova, J., \& Krizanova, A. (2014). Current State of the Advertising in the Process of Brand Value Building and Managing in Slovak Republic. 4th International Conference on Applied Social Science (ICASS), Advances in Education Research, Singapore, 2014, 144-149.

Masarova, G., Stefanikova, L., \& Rypakova, M. (2014) The Necessity of Obtaining Information Through Marketing Research in The Field of Pharmaceutical Companies on The Slovak Market, Procedia Economics and finance, 2014, 14801484.

Nadanyiova, M., \& Kramarova, K. (2013). Green marketing and its impacts on consumers' green purchasing behavior. International Scientific Conference on Marketing Identity: Design that Sells. 2013, 423-435.

Spolecnost pro fair trade (n.d.). The path of Fair Trade products. Retrieved from www: http://www.fairtrade.cz/cesta-fairtrade-vyrobku-1

Tokarcikova, E., Bartosova, V., Kucharcikova, A. \& Durisova, M. (2014). Automotive Company's Social Responsibility in Slovakia. 4th International-Business-Information-Management-Association Conference. I-IV, 2014, 2118-2127. 